\title{
Upaya Meningkatkan Penguasaan Kosakata dan Struktur Kalimat melalui Metode Diskusi Hasil Analisis Karya Tulis dengan Media Software Ginger pada Mata Kuliah Bahasa Inggris I
}

\author{
Sri Ariyanti Sabiku \\ Staf Pengajar Program Studi D3 Teknik Informatika, Politeknik Gorontalo \\ Email: riantisabiku@poligon.ac.id
}

ABSTRAK - Tujuan penelitian ini adalah sebagai berikut: (1) meningkatkan penguasaan kosakata dan struktur kalimat melalui metode diskusi hasil analisis karya tulis dengan media software ginger pada mata kuliah Bahasa Inggris I; (2) mengetahui langkah-langkah pembelajaran yang tepat; (3) mendeskripsikan respon mahasiswa mengenai proses pembelajaran kosakata dan struktur kalimat menggunakan metode diskusi dan media sofware ginger. Subjek penelitian terdiri dari: 20 orang mahasiswa Program Studi Teknik Informatika Politeknik Gorontalo Tahun Ajaran 2016/2017. Sedangkan, objek penelitian adalah hasil tes dan karya tulis mahasiswa, langkahlangkah pembelajaran, serta respon mahasiswa terhadap pembelajaran. Jenis penelitian yang digunakan adalah Penelitian Tindakan Kelas (PTK). Pengumpulan data dilakukan secara kualitatif melalui tes penguasaan kosakata dan struktur kalimat, observasi kemampuan dosen mengelola pembelajaran, serta kuisioner respon mahasiswa mengenai kegiatan pembelajaran. Teknik analisis data menggunakan teknik deskriptif secara kuantitatif dan kualitatif. Berdasarkan analisis data, penelitian ini membuktikan yaitu: pertama, tercapainya peningkatan dalam proses pembelajaran yang diwujudkan melalui penguasaan kosakata, dan struktur kalimat Bahasa Inggris dengan baik, serta mahasiswa mampu mengidentifikasi secara mandiri kesalahan penulisan pada sebuah karya tulis. Hal ini dilihat dari perbandingan tes kemampuan awal, siklus I dan siklus II menunjukkan adanya peningkatan dengan pemerolehan nilai yang memenuhi Kriteria Ketuntasan Minimal (KKM). Kedua, terdapat beberapa langkah pembelajaran dalam meningkatkan penguasaan kosakata dan struktur kalimat melalui metode diskusi hasil analisis karya tulis dengan media sofware ginger. Ketiga, mahasiswa memberikan respon yang baik terhadap pengimplementasian metode diskusi dan media sofware ginger dalam pembelajaran mata kuliah Bahasa Inggris $I$.

Kata Kunci: Kosakata, Struktur Kalimat, Karya Tulis, Bahasa Inggris, Metode Diskusi, Media Sofware Ginger

\section{PENDAHULUAN}

Bahasa Inggris dianggap menjadi penting sebagai dasar pendidikan dalam suatu program studi tertentu. Hal ini terlihat dengan adanya kebijakan kurikulum pada beberapa perguruan tinggi di Indonesia yang menggolongkan Bahasa Inggris baik sebagai Mata Kuliah Dasar Umum (MKDU) ataupun sebagai Mata Kuliah Pengembangan Kepribadian (MPK). Deskripsi tujuan Mata Kuliah Bahasa Inggris pada dasarnya direlevansikan sesuai dengan masing-masing sasaran bidang keilmuan/program studi tersebut.

Sebagaimana halnya pada program studi Diploma III Teknik Informatika di Politeknik Gorontalo, Mata Kuliah Bahasa Inggris diperoleh mahasiswa selama kurun waktu dua semester yaitu Bahasa Inggris I diawal semester, dan dilanjutkan dengan Bahasa Inggris II pada semester selanjutnya. Kedua Mata Kuliah Bahasa Inggris ini ditujukan dalam rangka menciptakan kualitas lulusan program studi yang tidak hanya terampil dan handal dibidang IT, namun dapat pula memiliki pengetahuan dan keterampilan berbahasa Inggris secara lisan maupun tulisan dengan baik, yang mampu menunjang keahlian para lulusan ketika terjun dalam dunia industri/kerja.

Mata Kuliah Bahasa Inggris 1 diajarkan kepada Mahasiswa Teknik Informatika dengan memberikan keterampilan/kemampuan awal menguasai kosakata dan konsep tata bahasa dasar misalnya: bagian-bagian dari bahasa, jenis dan bagian/struktur kalimat, tenses, fungsi bahasa lainnya mengacu kepada bidang studi Teknik Informatika dimana pengajarannya diintegrasikan ke dalam empat aspek keterampilan seperti, membaca, menulis, berbicara dan menyimak.

Berdasarkan pengamatan yang dilakukan peneliti selama masa pembelajaran Mata Kuliah Bahasa Inggris I, permasalahan krusial yang sering ditemui oleh dosen pengajar adalah masih rendahnya tingkat pengetahuan atau pemahaman mahasiswa terkait kosakata dan tata bahasa dasar seperti bagaimana menuliskan ejaan huruf dari sebuah kosakata dengan benar, mengkategorikan sesuai klasifikasi bagian atau unsur bahasa, menyusun struktur kalimat Bahasa Inggris secara tepat, serta pemilihan tenses sesuai konteksnya. Permasalahan ini kemudian sangat sering berpengaruh terhadap kualitas keterampilan berkomunikasi secara lisan ataupun tulisan yang mengalami banyak kesalahan. Hasil tes kemampuan awal mahasiswa membuktikan bahwa dari 20 orang mahasiswa yang menuliskan sebuah karya tulis berupa karangan pengalaman singkat berbahasa Inggris, terdapat 75\% mahasiswa memperoleh kategori skor sangat kurang atau tidak tuntas, $10 \%$ memperoleh kategori skor kurang atau diwajibkan mengikuti remedial, $10 \%$ dengan kategori cukup, dan hanya 5\% saja memperoleh kategori skor baik, bahkan untuk kategori skor sangat baik belum dapat diperoleh sama sekali. Sedangkan, menurut kriteria ketuntasan minimal yang

Upaya Meningkatkan Penguasaan Kosakata dan Struktur Kalimat melalui Metode Diskusi Hasil Analisis Karya Tulis dengan Media Software Ginger pada Mata Kuliah Bahasa Inggris I 
diharapkan sebagai indikator pencapaian kinerja dalam pembelajaran ini, adalah 70\% mahasiswa mampu memiliki ketuntasan dengan nilai 70 pada tingkat kategori skor baik.

Hasil evaluasi tulisan mahasiswa menggambarkan tingkat kesukaran yang paling banyak ditonjolkan terdapat pada capaian pembelajaran yaitu kemampuan menguasai perbendaharaan kata dan struktur kalimat menurut kaidahnya. Padahal disisi lain, capaian pembelajaran ini sangatlah penting untuk dapat dituntaskan oleh mahasiswa dengan skor baik mengingat aspek-aspek indikator di dalamnya juga cukup berpengaruh sebagai salah satu kunci dalam meraih keberhasilan tes uji kemahiran berbahasa Inggris seperti TOEFL. Dengan mempertimbangan situasi ini maka penguasaan kosakata dan konsep tata bahasa khususnya struktur kalimat seharusnya mendapat perhatian secara intensif dari dosen pengajar.

Untuk mempelajari tata bahasa dasar diantaranya seperti menyusun ejaan dari kosakata yang benar, dan struktur kalimat berbahasa Inggris disadari memang bukan persoalan yang mudah terhadap pembelajar Bahasa Inggris sebagai bahasa asing. Perbedaan dalam hal struktur Bahasa Indonesia dan Bahasa Inggris merupakan satu dari penyebab terjadinya permasalahan ini. Berbagai macam perbedaan dalam kedua bahasa tersebut seperti perbedaan pengejaan, penempatan jenis kata dan bentuk tenses juga menjadi kendala bagi pembelajar Bahasa Inggris di Indonesia khususnya yang dihadapi pada mahasiswa program studi Teknik Informatika Politeknik Gorontalo.

Hambatan lain adalah rata-rata pada umumnya metode pengajaran dosen masih berupa metode ceramah. Rumus atau pola-pola tata bahasa masih disampaikan dalam bentuk penuturan dan penyampaian berdasarkan topiknya secara langsung, kemudian dihafalkan mahasiswa. Penyampaian materi Bahasa Inggris belum sepenuhnya menerapkan komunikasi dua arah antara pengajar dan mahasiswa secara maksimal, disebabkan oleh kurangnya keaktifan mahasiswa untuk mengekspresikan gagasan menggunakan bahasa target yakni Bahasa Inggris. Pada akhirnya penggunaan metode ceramah menjadikan suasana pembelajaran di kelas lebih mengarah kepada situasi pembelajaran yang terpusat penuh pada dosen pengajar atau dengan kata lain teacher-centered, tanpa adanya keaktifan mahasiswa dengan porsi yang lebih banyak. Keadaan ini konsekuensinya memicu rasa bosan, tidak semangat karena minat belajar semakin berkurang.

Disamping itu, keterbatasan fasilitas, waktu dan kurangnya strategi pemilihan/pemanfaatan media pembelajaran menarik, bervariasi dan mampu memotivasi minat mahasiswa menjadi kendala terwujudnya keberhasilan penyampaian materi secara efektif. Padahal Media pembelajaran merupakan bagian integral dalam sistem pembelajaran itu sendiri. Djamarah \& Zain (2010:121) menjelaskan pengertian media adalah "alat bantu apa saja yang dapat dijadikan sebagai penyalur pesan guna mencapai tujuan pengajaran. Selanjutnya, Sumiati dan Asra(2008:160) mengemukakan media pembelajaran diartikan "sebagai segala sesuatu yang dapat digunakan untuk menyalurkan pesan (message), merangsang pikiran, perasaan, perhatian, dan kemauan siswa sehingga dapat mendorong proses belajar.”

Demi tercapainya keberhasilan pembelajaran, unsur pendukung untuk memecahkan persoalan ini ditentukan salah satunya oleh dosen pengajar itu sendiri. Peran penting dosen dalam menjalankan proses pembelajaran adalah memastikan keseluruhan aspek yang dirancang berjalan lancar dan mampu mensukseskan indikator capaian pembelajaran pada suatu mata kuliah tertentu. Menurut Harmer (2001:57) terdapat 8 peran pengajar dalam proses pembelajaran yakni sebagai berikut: (1)sebagai pengontrol (controller), (2)sebagai pelaksana (organisator), (3)sebagai penilai (assessor), (4)sebagai pendorong (prompter), (5)sebagai partisipan (peserta), (6)sebagai sumber (resource), (7)sebagai tutor, (8)sebagai pengamat (observer). Penjabaran deskripsi peran dari Harmer ini menerangkan dengan jelas bahwa sebagai pelaksana dan juga pengembang kurikulum, seorang dosen turut mengambil andil mensukseskan pembelajarannya dengan memilih dan mengembangkan materi, strategi, model, metode, teknik, dan media yang sesuai dengan kebutuhan pembelajar.

Seiring dengan perkembangan teknologi yang sangat pesat, beragam media pembelajaran diciptakan untuk dapat dimanfaatkan pada segala macam kondisi. Klasifikasi jenis media pembelajaran menurut Heinich dkk, 1996 sebagai berikut: Media yang tidak diproyeksikan, media yang diproyeksikan, media Audio, Media Video, Media berbasis Komputer, dan Multi media Kit. (dikutip dalam buku Pribadi \& Putri, 2001:3) Penggunaan media pembelajaran secara tepat akan dapat memperbesar arti dan fungsi dalam menunjang efektifitas serta efisiensi proses pembelajaran yang ingin dicapai. Dalam dunia pendidikan proses pembelajaran pun telah dapat dilakukan dengan penggunaan media berbasis teknologi misalnya melalui software-software tertentu yang dapat mempermudah pengajar maupun pembelajar menyelesaikan suatu permasalahan pembelajaran dengan cepat, mudah, dan akurat. Software atau yang disebut dengan perangkat lunak merupakan kumpulan data elektronik yang disimpan dan diatur oleh komputer. Data yang disimpan dan diatur ini dapat berupa program atau instruksi yang akan menjalankan suatu perintah. Berbagai macam jenis software yang bermunculan ini diantaranya menyediakan jenis fasilitas yang bebas, berbayar, shareware dan lain sebagainya.

Oleh karena itu, untuk memperoleh solusi dalam menangani kesulitan pembelajaran berdasarkan uraian data sebelumnya, maka peneliti mencoba untuk mengujicobakan suatu metode diskusi hasil analisis karya tulis dengan menggunakan media sofware ginger untuk meningkatkan penguasaan kosakata dan struktur kalimat Bahasa Inggris. Menurut Rianto, M (2006:55) “Diskusi merupakan cara penyajian materi pelajaran dengan tukar-menukar pendapat untuk mencari pemecahan permasalahan tentang suatu topik tertentu. Melalui diskusi peserta didik termotivasi untuk belajar secara aktif dan saling mengembangkan pendapatnya sendiri dalam memecahkan suatu topik permasalahan.” Sedangkan, sebagaimana dikutip melalui laman http://www.gingersoftware.com menjelaskan bahwa software ginger dapat menjadi alat bantu dalam mengecek ejaan dari 
kosakata, dan tata bahasa secara kontekstual pada tulisan Bahasa Inggris. Software ini dapat digunakan baik oleh pengajar atau pembelajar dengan cara menginstal aplikasi pada desktop dengan fasilitas free ataupun premium yang ditambah fitur-fitur penunjang lainnya, dengan maksud dapat menjadi alternatif media yang menarik minat dan perhatian pembelajaran. Melalui pengintegrasian cara pengajaran menggunakan metode dan media ini, maka peneliti ingin menemukan hasil dari peningkatan penguasaan mahasiswa terhadap kosakata dan struktur kalimat Bahasa Inggris.

Pengujian keefektifan penggunaan metode dan media ini dikaji oleh peneliti melalui rancangan suatu penelitian tindakan kelas. Tujuan dari penelitian tindakan kelas ini adalah (1)untuk mengujicobakan apakah metode diskusi hasil analisis karya tulis dengan media software ginger mampu meningkatkan penguasaan kosakata dan struktur kalimat, (2)untuk mengetahui langkah-langkah pembelajaran yang tepat menerapkannya, (3)untuk menggambarkan respon mahasiswa terhadap penggunaan metode diskusi dan media software ginger.

\section{METODE PENELITIAN}

\subsection{Lokasi Penelitian}

Penelitian dilaksanakan di Kampus Politeknik Gorontalo, Desa Panggulo Barat, Kecamatan Botupingge, Kabupaten Bone Bolango. Penelitian dilaksanakan selama 2 bulan pada Semester Ganjil Tahun Ajaran 2016/2017. Penelitian tersebut dimulai sejak minggu pertama bulan November, yakni: pada tanggal 3 November 2016 sampai dengan minggu terakhir bulan Desember, pada tanggal 22 Desember 2016. Kemudian dilanjutkan dengan proses penyusunan laporan penelitian selama satu bulan.

\subsection{Jenis Penelitian}

Penelitian ini merupakan Penelitian Tindakan Kelas (PTK) yang dilaksanakan secara kolaboratif dan partisipatif. Yang dimaksud dengan kolaboratif adalah peneliti melakukan kerja sama dengan dosen lainnya, sedangkan partisipatif adalah peneliti dalam melaksanakan penelitian ini dibantu oleh teman sejawat yang berperan sebagai observer. Pengamat dalam penelitian ini adalah saudara Alfian Usman, S.Pd.,M.Hum (DLB di bidang Bahasa Politeknik Gorontalo). Terdapat beberapa tahapan yang dilakukan dalam penelitian tindakan kelas sebagaimana yang diadaptasi dari Arikunto dkk (2007:16) yakni (1)Tahap Perencanaan Tindakan atau Planning, (2)Tahap Implementasi Tindakan atau Acting, (3)Tahap Pengamatan atau Observing, (4)Tahap Refleksi atau Reflecting pada setiap siklus yang dijalankan.

\subsection{Subjek Penelitian}

Subjek yang digunakan dalam penelitian ini terdiri dari 20 orang mahasiswa Teknik Informatika Kelas C Semester 1 Tahun Ajaran 2016/2017. Pengambilan subjek ini dilaksanakan berdasarkan keputusan dan kesepakatan dosen yang dilatarbelakangi atas hasil kemampuan mahasiswa di kelas tersebut perlu ditingkatkan dalam penguasaan kosakata, dan struktur kalimatnya.

\subsection{Prosedur Penelitian}

Prosedur penelitian yang dilakukan dalam penelitian ini terdiri dari 2 Siklus. Pada setiap siklus dilaksanakan berdasarkan perubahan yang ingin dicapai oleh peneliti. Berikut pemaparan mengenai masing-masing tahapan penelitian:

\section{a. Tahap Perencanaan Tindakan atau Planning:}

Dalam tahap perencanaan tindakan, peneliti melakukan perancangan kegiatan dalam memperbaiki kemampuan mahasiswa sebagai berikut: Perencanaan tindakan ini dilaksanakan dengan melakukan pengamatan mengenai kemampuan awal mahasiswa, berkoordinasi dengan dosen lainnya, melakukan pre-test, menyusun skenario pembelajaran menggunakan metode diskusi hasil analisis karya tulis dengan media software ginger yang dijabarkan dalam Satuan Acara Perkuliahan. Kemudian menyiapkan media pembelajaran berupa software ginger yang diinstal pada PC atau Personal Computer pengajar dan dapat ditayangkan melalui LCD Proyektor, menyiapkan lembar pengamatan baik untuk mahasiswa dan dosen terkait kondisi pembelajaran di kelas pada saat diterapkannya metode diskusi dengan media berupa software ginger serta mempersiapkan instrumen alat evaluasi untuk mengukur apakah kemampuan kosakata dan struktur kalimat Bahasa Inggris mengalami peningkatan yang dapat diwujudkan dengan berkurangnya tingkat kesalahan penulisan kosakata serta struktur kalimat Bahasa Inggris pada hasil tes evaluasi jawaban mahasiswa dan karangan singkat.

\section{b. Tahap Implementasi Tindakan atau Acting:}

Tahap implementasi tindakan dilakukan sesuai dengan skenario pembelajaran yang telah direncakanan oleh peneliti. Implementasi tindakan dilaksanakan sebanyak dua siklus. Siklus pertama dilaksanakan sebanyak empat kali pertemuan dan siklus kedua dilakukan sebanyak empat kali pertemuan. Masing-masing pertemuan berdurasi selama 2 x 50 menit atau 100 menit.

\section{c. Tahap Pengamatan atau Observing:}

Tahap pengamatan atau observasi dilaksanakan sesuai dengan indikator penilaian pengamatan yang telah dipersiapkan sebelumnya oleh peneliti melalui lembar pengamatan kegiatan dosen dan mahasiswa selama proses pembelajaran dilangsungkan. Jadi proses pengamatan ini dijalankan secara bersamaan dengan implementasi tindakan. Pada tahap ini, pengamatan meliputi keterampilan, sikap dan pengetahuan mahasiswa terhadap kosakata dan struktur kalimat Bahasa Inggris.

\section{d. Tahap Refleksi atau Reflecting:}

Tahap refleksi merupakan tahap pengumpulan dan analisis data berdasarkan hasil pemerolehan dari tahap pengamatan yang dilakukan sebelumnya. Hasil pengamatan yang diperoleh oleh peneliti maka dapat memberikan refleksi diri kepada peneliti mengenai kegiatan yang dilaksanakan apakah dapat meningkatkan penguasaan kosakata dan struktur kalimat Bahasa Inggris. Sehingga hal tersebut bisa memberikan 
dampak secara positif terhadap berkurangnya tingkat kesalahan penulisan karya tulis mahasiswa berupa karangan singkat. Hasil analisis data yang diperoleh, selanjutnya menjadi acuan atau pertimbangan peneliti apakah sesuai dengan hasil yang ditetapkan pada kriteria ketuntasan minimal atau sebaliknya, dan kemudian mendapat modifikasi untuk dipecahkan pada rencana tindakan di siklus selanjutnya.

\subsection{Teknik Pengumpulan Data}

Teknik pengumpulan data yang digunakan dalam penelitian ini adalah sebagai berikut: (a) metode observasi dengan menggunakan instrumen lembar observasi untuk melihat aktifitas dosen dan mahasiswa dalam proses pembelajaran Bahasa Inggris menggunakan metode diskusi dengan media software ginger, (b) metode tes yang diperoleh datanya melalui pre-test dan post-test berupa soal kosakata dan struktur kalimat seperti word or sentence arrangement serta essay singkat sesuai topik untuk mengukur tingkat pemahaman penguasaan kosakata dan struktur kalimat. (c) angket dalam mengetahui respon mahasiswa terkait metode dan media yang digunakan.

\subsection{Teknik Analisis Data}

Analisis data dilakukan secara bertahap dan berkesinambungan pada saat pengumpulan data dirampungkan. Dengan melihat pada akhir siklus, peneliti membahas data masalah tersebut secara berkolaborasi dengan seluruh pihak yang terlibat dalam penelitian tindakan kelas ini. Tujuan analisis data ini untuk melihat dampak dari tindakan yang telah diujicobakan kepada subjek penelitiannya dengan maksud dan harapan akan lebih secara efektif sesuai dengan kualitas tindakan yang dikembangkan secara berkelanjutan.

Penelitian ini menggunakan teknik analisis data secara deskriptif kualitatif dan kuantitatif. Teknik analisis deskriptif kualitatif menjabarkan data yang dikumpulkan melalui observasi dan teknik analisis deskriptif kuantitatif menjabarkan data yang diperoleh melalui tes tertulis berupa skor hasil tes mahasiswa. Hasil skor pre-test dan post-test dibandingkan satu sama lainnya untuk mengetahui peningkatan penguasaan kosakata dan struktur kalimat Bahasa Inggris pada mahasiswa kelas C Program Studi Teknik Informatika di Politeknik Gorontalo. Pengujian hipotesis tindakan ini dihasilkan berdasarkan hasil tes penguasan kosakata dan struktur kalimat Bahasa Inggris yang diperoleh mahasiswa. Hipotesis penelitian tindakan ini dapat dinyatakan diterima jika indikator keberhasilan tindakan yang dilaksanakan oleh peneliti telah tercapai.

\section{HASIL PENELITIAN DAN PEMBAHASAN}

\subsection{Hasil Penelitian}

Penelitian ini dilaksanakan ke dalam 2 siklus. Siklus pertama dan kedua masing-masing terdiri dari 4x pertemuan dengan konten materi/tema yang menekankan pada konsep "Kosakata dan Struktur Kalimat. Siklus I dan Siklus II berjumlah sebanyak delapan kali dengan tema yang bervariasi.

\subsubsection{Hasil Penguasan Kosakata dan Struktur Kalimat}

Adapun perbandingan data hasil kemampuan awal mahasiswa dengan data hasil penguasaan kosakata dan struktur kalimat setelah dilaksanakannya siklus I dan siklus II dapat dijabarkan dalam beberapa tabel sebagai berikut:

Tabel 1. Data Hasil Kemampuan Awal Mahasiswa

\begin{tabular}{|ccccc|}
\hline \multicolumn{5}{c|}{ KATEGORI PENILAIAN } \\
\hline $\begin{array}{c}\text { Sangat } \\
\text { Baik }\end{array}$ & $\begin{array}{c}\text { Bai } \\
\text { k }\end{array}$ & $\begin{array}{c}\text { Cuku } \\
\text { p }\end{array}$ & Kurang & Sangat Kurang \\
\hline- & $\mathbf{5 \%}$ & $\mathbf{1 0 \%}$ & $\mathbf{1 0 \%}$ & $\mathbf{7 5 \%}$ \\
\hline
\end{tabular}

Tabel 2.Data Hasil Persentase Penguasaan Kosakata Siklus I

\begin{tabular}{|ccccc|}
\hline \multicolumn{5}{c|}{ KATEGORI PENILAIAN } \\
\hline $\begin{array}{c}\text { Sangat } \\
\text { Baik }\end{array}$ & Baik & $\begin{array}{c}\text { Cuku } \\
\mathbf{p}\end{array}$ & Kurang & Sangat Kurang \\
\hline $\mathbf{2 0} \%$ & $\mathbf{4 0 \%}$ & $\mathbf{2 5 \%}$ & $\mathbf{1 5 \%}$ & - \\
\hline
\end{tabular}

Tabel 3.Data Hasil Persentase Penguasaan Struktur Kalimat Siklus I

\begin{tabular}{|ccccc|}
\hline \multicolumn{5}{|c|}{ KATEGORI PENILAIAN } \\
\hline Sangat Baik & Baik & Cukup & Kurang & $\begin{array}{c}\text { Sangat } \\
\text { Kurang }\end{array}$ \\
\hline $\mathbf{1 0 \%}$ & $\mathbf{4 0 \%}$ & $\mathbf{2 5 \%}$ & $\mathbf{2 5 \%}$ & - \\
\hline
\end{tabular}

Tabel 4.Data Hasil Persentase Penguasaan Kosakata Siklus II

\begin{tabular}{|ccccc|}
\hline Sangat Baik & Baik & $\begin{array}{c}\text { Cuku } \\
\mathbf{p}\end{array}$ & Kurang & $\begin{array}{c}\text { Sangat } \\
\text { Kurang }\end{array}$ \\
\hline $\mathbf{3 0 \%}$ & $\mathbf{5 0 \%}$ & $\mathbf{2 0 \%}$ & - & - \\
\hline
\end{tabular}

Tabel 5.Data Hasil Persentase Penguasaan Struktur Kalimat Siklus II

\begin{tabular}{|ccccc|}
\hline $\begin{array}{c}\text { Kangat } \\
\text { Baik }\end{array}$ & Baik & Cukup & Kurang & $\begin{array}{c}\text { Sangat } \\
\text { Kurang }\end{array}$ \\
\hline $35 \%$ & $\mathbf{4 0 \%}$ & $\mathbf{2 5 \%}$ & - & - \\
\hline
\end{tabular}

Tabel 6. Data Hasil Skor Penguasan Kosakata

\begin{tabular}{|c|c|c|c|c|}
\hline \multirow{2}{*}{$\begin{array}{l}\text { SUBYE } \\
\text { K }\end{array}$} & \multicolumn{4}{|c|}{$\begin{array}{c}\text { SUMBER DATA } \\
\text { PENGUASAAN KOSAKATA }\end{array}$} \\
\hline & $\begin{array}{l}\text { SIKLU } \\
\text { S I }\end{array}$ & KRITERIA & $\begin{array}{l}\text { SIKLU } \\
\text { S II }\end{array}$ & KRITERIA \\
\hline YM & 80 & Baik & 88 & Sangat Baik \\
\hline JA & 80 & Baik & 84 & Baik \\
\hline NH & 88 & Sangat Baik & 92 & Sangat Baik \\
\hline AFA & 80 & Baik & 84 & Baik \\
\hline AH & 52 & $\begin{array}{l}\text { Sangat } \\
\text { Kurang }\end{array}$ & 68 & Cukup \\
\hline AA & 88 & Sangat Baik & 92 & Sangat Baik \\
\hline $\mathbf{A M}$ & 72 & Baik & 80 & Baik \\
\hline
\end{tabular}




\begin{tabular}{|ccccc|}
\hline DU & 92 & Sangat Baik & 96 & Sangat Baik \\
\hline IS & 52 & $\begin{array}{c}\text { Sangat } \\
\text { Kurang }\end{array}$ & 68 & Cukup \\
\hline ID & 80 & Baik & 84 & Baik \\
\hline LE & 68 & Cukup & 72 & Baik \\
\hline MM & 96 & Sangat Baik & 100 & Sangat Baik \\
\hline RM & 60 & Cukup & 68 & Cukup \\
\hline RS & 72 & Baik & 88 & Baik \\
\hline SA & 60 & Cukup & 68 & Cukup \\
\hline SI & 60 & Cukup & 80 & Baik \\
\hline TM & 80 & Baik & 92 & Sangat Baik \\
\hline MZ & 52 & Sangat & 72 & Baik \\
\hline WM & 60 & Cukup & 72 & Baik \\
\hline RY & 72 & Baik & 80 & Baik \\
\hline
\end{tabular}

Tabel.7 Data Hasil Skor Penguasaan Struktur Kalimat

\begin{tabular}{|c|c|c|c|c|}
\hline \multirow{2}{*}{$\begin{array}{l}\text { SUBYE } \\
\text { K }\end{array}$} & \multicolumn{4}{|c|}{$\begin{array}{c}\text { SUMBER DATA } \\
\text { PENGUASAAN STRUKTUR KALIMAT }\end{array}$} \\
\hline & $\begin{array}{c}\text { SIKLU } \\
\text { S I }\end{array}$ & KRITERIA & $\begin{array}{c}\text { SIKLU } \\
\text { S II }\end{array}$ & $\begin{array}{c}\text { KRITERI } \\
\text { A }\end{array}$ \\
\hline YM & 72 & Baik & 80 & Baik \\
\hline JA & 72 & Baik & 84 & Baik \\
\hline NH & 88 & Sangat Baik & 88 & $\begin{array}{c}\text { Sangat } \\
\text { Baik }\end{array}$ \\
\hline AFA & 72 & Baik & 96 & $\begin{array}{c}\text { Sangat } \\
\text { Baik }\end{array}$ \\
\hline AH & 52 & $\begin{array}{l}\text { Sangat } \\
\text { Kurang }\end{array}$ & 60 & Cukup \\
\hline AA & 80 & Baik & 92 & $\begin{array}{c}\text { Sangat } \\
\text { Baik }\end{array}$ \\
\hline $\mathbf{A M}$ & 60 & Cukup & 80 & Baik \\
\hline DU & 80 & Baik & 96 & $\begin{array}{c}\text { Sangat } \\
\text { Baik }\end{array}$ \\
\hline IS & 52 & $\begin{array}{l}\text { Sangat } \\
\text { Kurang }\end{array}$ & 60 & Cukup \\
\hline ID & 80 & Baik & 84 & Baik \\
\hline LE & 60 & Cukup & 72 & Baik \\
\hline MM & 88 & Sangat Baik & 96 & $\begin{array}{l}\text { Sangat } \\
\text { Baik }\end{array}$ \\
\hline $\mathbf{R M}$ & 68 & Cukup & 72 & Baik \\
\hline RS & 60 & Cukup & 92 & $\begin{array}{c}\text { Sangat } \\
\text { Baik }\end{array}$ \\
\hline SA & 52 & $\begin{array}{c}\text { Sangat } \\
\text { Kurang }\end{array}$ & 60 & Cukup \\
\hline SI & 72 & Baik & 80 & Baik \\
\hline TM & 80 & Baik & 96 & $\begin{array}{c}\text { Sangat } \\
\text { Baik }\end{array}$ \\
\hline MZ & 52 & $\begin{array}{l}\text { Sangat } \\
\text { Kurang }\end{array}$ & 60 & Cukup \\
\hline WM & 52 & $\begin{array}{l}\text { Sangat } \\
\text { Kurang }\end{array}$ & 60 & Cukup \\
\hline RY & 60 & Cukup & 72 & Baik \\
\hline
\end{tabular}

\subsubsection{Hasil Pengamatan Kegiatan Pembelajaran}

Tabel 8. Data Hasil Pengamatan Kegiatan Dosen

\begin{tabular}{ccccc}
\hline \multicolumn{5}{c}{ PENGAMATAN KBM (DOSEN) SIKLUS I } \\
\hline Sangat & Bai & Cuku & Kurang & Sangat Kurang \\
Baik & $\mathbf{k}$ & $\mathbf{p}$ & & - \\
$32 \%$ & 52 & $\mathbf{1 6 \%}$ & - & \\
\multicolumn{5}{c}{$\%$} \\
PENGAMATAN KBM (DOSEN)
\end{tabular}

Tabel 9. Data Hasil Pengamatan Kegiatan Mahasiswa

\begin{tabular}{ccccc}
\multicolumn{5}{c}{ PENGAMATAN KBM (MAHASISWA) SIKLUS I } \\
\hline Sangat & Bai & Cuku & Kurang & Sangat Kurang \\
Baik & $\mathbf{k}$ & $\mathbf{p}$ & & - \\
- & 33 & $50 \%$ & $17 \%$ & - \\
\multicolumn{5}{c}{$\%$} \\
PENGAMATAN KBM (MAHASISWA) SIKLUS II \\
Sangat & Bai & Cuku & Kurang & Sangat Kurang \\
Baik & $\mathbf{k}$ & $\mathbf{p}$ & & \\
$17 \%$ & 83 & - & - & - \\
& $\%$ & & & \\
\hline
\end{tabular}

\subsubsection{Hasil Data Balikan Respon Mahasiswa}

Tabel 10. Data Respon Mahasiswa Terhadap Proses dan Minat dalam Kegiatan Belajar Mengajar

\begin{tabular}{|cllcc|}
\hline \multirow{3}{*}{$\begin{array}{c}\text { ASPE } \\
\text { K }\end{array}$} & \multicolumn{1}{c}{ SIKLUS I } & \multicolumn{3}{c}{ NILAI } \\
& & \multicolumn{3}{c}{ PERSENTASE } \\
\cline { 3 - 5 } & & $\mathbf{( \% )}$ \\
\hline & Suasana Perkuliahan & 60 & 30 & 10 \\
& & $\%$ & $\%$ & $\%$ \\
\cline { 2 - 5 } PROS & Cara Dosen Mengajar & 60 & 35 & 10 \\
ES & & $\%$ & $\%$ & $\%$ \\
\cline { 2 - 5 } KBM & Pengunaan Metode & 70 & 15 & 15 \\
& Pembelajaran & $\%$ & $\%$ & $\%$ \\
\cline { 2 - 5 } & Penggunaan Media & 60 & 30 & 10 \\
& Pembelajaran & $\%$ & $\%$ & $\%$ \\
\cline { 2 - 5 } & Pemahaman Materi & 65 & 15 & 20 \\
& Pembelajaran & $\%$ & $\%$ & $\%$ \\
\cline { 2 - 5 } & Interaksi Dosen dengan & 70 & 20 & 10 \\
& Mahasiswa & $\%$ & $\%$ & $\%$ \\
\cline { 2 - 5 } & Interaksi Mahasiswa dengan & 60 & 30 & 10 \\
& Mahasiswa & $\%$ & $\%$ & $\%$ \\
\cline { 2 - 5 } & Interaksi Mahasiswa dengan & 30 & 65 & $5 \%$ \\
& Dosen & $\%$ & $\%$ & \\
\hline & & & & \\
\hline
\end{tabular}




\begin{tabular}{|c|c|c|c|c|}
\hline \multirow{5}{*}{$\underset{T}{\text { MINA }}$} & $\begin{array}{l}\text { Ketertarikan dengan Mata } \\
\text { Kuliah Bahasa Inggris I }\end{array}$ & $\begin{array}{l}60 \\
\%\end{array}$ & $\begin{array}{l}35 \\
\%\end{array}$ & $5 \%$ \\
\hline & $\begin{array}{l}\text { Keinginan untuk } \\
\text { mempelajari lebih dalam } \\
\text { topik materi yang diajarkan }\end{array}$ & $\begin{array}{l}55 \\
\%\end{array}$ & $\begin{array}{l}35 \\
\%\end{array}$ & $\begin{array}{l}10 \\
\%\end{array}$ \\
\hline & $\begin{array}{l}\text { Ketidakjenuhan belajar } \\
\text { melalui metode } \\
\text { pembelajaran yang } \\
\text { diterapkan }\end{array}$ & $\begin{array}{l}70 \\
\%\end{array}$ & $\begin{array}{l}20 \\
\%\end{array}$ & $\begin{array}{l}10 \\
\%\end{array}$ \\
\hline & $\begin{array}{l}\text { Ketidakjenuhan belajar } \\
\text { menggunakan media } \\
\text { pembelajaran }\end{array}$ & $\begin{array}{l}65 \\
\%\end{array}$ & $\begin{array}{l}30 \\
\%\end{array}$ & $5 \%$ \\
\hline & $\begin{array}{l}\text { Keinginan untuk mengikuti } \\
\text { perkuliahan pada tahap } \\
\text { selanjutnya }\end{array}$ & $\begin{array}{l}60 \\
\%\end{array}$ & $\begin{array}{l}40 \\
\%\end{array}$ & - \\
\hline
\end{tabular}

Tabel 11. Data Respon Mahasiswa Terhadap Proses dan Minat dalam Kegiatan Belajar Mengajar SIKLUS II

\begin{tabular}{|c|c|c|c|c|}
\hline \multirow[t]{2}{*}{ ASPEK } & \multirow[t]{2}{*}{ INDIKATOR } & \multicolumn{3}{|c|}{$\begin{array}{c}\text { NILAI } \\
\text { PERSENTASI } \\
(\%)\end{array}$} \\
\hline & & SB & B & KB \\
\hline \multirow{16}{*}{$\begin{array}{l}\text { PROSE } \\
\text { S KBM }\end{array}$} & \multirow[t]{2}{*}{ Suasana Perkuliahan } & 70 & 25 & \multirow[t]{2}{*}{$5 \%$} \\
\hline & & $\%$ & $\%$ & \\
\hline & \multirow[t]{2}{*}{ Cara Dosen Mengajar } & 75 & 20 & \multirow[t]{2}{*}{$5 \%$} \\
\hline & & $\%$ & $\%$ & \\
\hline & \multirow{2}{*}{$\begin{array}{l}\text { Pengunaan Metode } \\
\text { Pembelajaran }\end{array}$} & 75 & 15 & 10 \\
\hline & & $\%$ & $\%$ & \multirow{2}{*}{$\begin{array}{c}\% \\
5 \%\end{array}$} \\
\hline & \multirow{2}{*}{$\begin{array}{l}\text { Penggunaan Media } \\
\text { Pembelajaran }\end{array}$} & 70 & 25 & \\
\hline & & $\%$ & $\%$ & \\
\hline & Pemahaman Materi & 75 & 20 & \multirow[t]{2}{*}{$5 \%$} \\
\hline & Pembelajaran & $\%$ & $\%$ & \\
\hline & \multirow{2}{*}{$\begin{array}{l}\text { Interaksi Dosen dengan } \\
\text { Mahasiswa }\end{array}$} & 70 & 25 & \multirow[t]{2}{*}{$5 \%$} \\
\hline & & $\%$ & $\%$ & \\
\hline & \multirow{2}{*}{$\begin{array}{l}\text { Interaksi Mahasiswa } \\
\text { dengan Mahasiswa }\end{array}$} & 85 & 15 & \multirow[t]{2}{*}{$0 \%$} \\
\hline & & $\%$ & $\%$ & \\
\hline & \multirow{2}{*}{$\begin{array}{l}\text { Interaksi Mahasiswa } \\
\text { dengan Dosen }\end{array}$} & 60 & 30 & \multirow{2}{*}{$\begin{array}{l}10 \\
\%\end{array}$} \\
\hline & & $\%$ & $\%$ & \\
\hline \multirow{11}{*}{$\begin{array}{l}\text { MINA } \\
\quad \text { T }\end{array}$} & \multirow{2}{*}{$\begin{array}{l}\text { Ketertarikan dengan Mata } \\
\text { Kuliah Bahasa Inggris I }\end{array}$} & 70 & 25 & \multirow[t]{2}{*}{$5 \%$} \\
\hline & & $\%$ & $\%$ & \\
\hline & \multirow{2}{*}{$\begin{array}{l}\text { Keinginan untuk } \\
\text { mempelajari lebih dalam } \\
\text { topik materi yang diajarkan }\end{array}$} & 80 & 15 & \multirow[t]{2}{*}{$5 \%$} \\
\hline & & $\%$ & $\%$ & \\
\hline & \multirow{3}{*}{$\begin{array}{l}\text { Ketidakjenuhan belajar } \\
\text { melalui metode } \\
\text { pembelajaran yang } \\
\text { diterapkan }\end{array}$} & 75 & 20 & \multirow[t]{3}{*}{$5 \%$} \\
\hline & & $\%$ & $\%$ & \\
\hline & & & & \\
\hline & \multirow{2}{*}{$\begin{array}{l}\text { Ketidakjenuhan belajar } \\
\text { menggunakan media } \\
\text { pembelajaran }\end{array}$} & 75 & 20 & \multirow[t]{2}{*}{$5 \%$} \\
\hline & & $\%$ & $\%$ & \\
\hline & \multirow{2}{*}{$\begin{array}{l}\text { Keinginan untuk mengikuti } \\
\text { perkuliahan pada tahap } \\
\text { selanjutnya }\end{array}$} & 80 & 20 & \multirow[t]{2}{*}{-} \\
\hline & & $\%$ & & \\
\hline
\end{tabular}

\subsection{PEMBAHASAN}

Berdasarkan hasil uraian data penelitian yang telah dijabarkan sebelumnya, maka dapat dilihat adanya peningkatan penguasaan kosakata dan struktur kalimat mahasiswa melalui pengimplementasian metode diskusi hasil analisis karya tulis dengan media software ginger. Peningkatan dibuktikan melalui perbandingan capaian persentase kategori penilaian kemampuan seluruh mahasiswa. Sebagaimana penyajian data kemampuan awal, sebesar $75 \%$ mahasiswa memperoleh kategori penilaian "sangat kurang atau tidak tuntas”, Setelah dilakukannya pengimplementasian sebanyak 2 siklus, mahasiswa mampu mencapai KKM yang ditetapkan dengan bobot 70 . Hasil terakhir menunjukan $80 \%$ dari mahasiswa memenuhi KKM untuk penguasaan kosakata, dan $75 \%$ untuk penguasaan struktur kalimat.

Selanjutnya, pada proses pelaksanaan kegiatan belajar mengajar baik siklus I dan siklus II, peneliti diobservasi oleh dosen mitra/teman sejawat dengan menggunakan lembar pengamatan kegiatan pembelajaran untuk dosen dan mahasiswa. Beberapa aspek yang diamati mulai dari tahap persiapan sampai pada pelaksanaannya meliputi kegiatan pendahuluan, kegiatan inti dan kegiatan penutup. Hasil pengamatan menunjukan bahwa proses KBM antara dosen dan mahasiswa berjalan dengan baik dan mengalami peningkatan disetiap siklusnya. Meskipun demikian, terdapat sejumlah perbaikan yang dilakukan pada siklus II dikarenakan beberapa kelemahan pada hasil refleksi yang ditemukan di Siklus I. Hasil refleksi perbaikan yang perlu mendapatkan pengembangan adalah aspek pengelolaan kelas oleh dosen yang belum berjalan secara maksimal, pengelolaan interaksi, pemberian reward,serta alokasi waktu mengimplementasikan metode dan media. Sedangkan untuk kegiatan mahasiswa meliputi penekanan untuk perbaikan cara bekerja sama dan interaksi dalam kelompok diskusi agar seimbang dan tidak didominasi oleh sekelompok atau individu tertentu, kedisiplinan mahasiswa, tanggung jawab terhadap hasil kerja (tugas karya tulis), dan kemampuan mahasiswa dalam menarik kesimpulan pembelajaran. Namun pada akhirnya, seperti yang ditampilkan dalam tabel data proses KBM cukup mengalami peningkatan pada siklus II dan mampu memperbaiki hasil refleksi kekurangan-kekurangan pembelajaran pada siklus I.

Kemudian disamping itu, data hasil respon mahasiswa terkait proses KBM dan minat terhadap pengimplementasian metode dan media dalam pembelajaran menunjukan adanya perbedaan persentase. Dalam hal ini, setiap indikator penilaian menunjukan rata-rata mahasiswa mempunyai respon KBM dan minat yang baik terhadap penerapan metode dan media ini untuk meningkatkan penguasaan kosakata dan struktur kalimat. Data menunjukan bahwa tidak lebih dari 20\% mahasiswa yang mengatakan KBM dengan kategori $\mathrm{KB}$ atau Kurang Baik. Selain dari jumlah yang ditampilkan dalam tabel, persentase rata-rata mahasiswa banyak yang memilih kategori Sangat Baik dan Baik, bahkan tidak ada sama sekali mahasiswa yang menyatakan untuk tidak tertarik dalam melanjutkan perkuliahan pada tahap selanjutnya. Artinya dapat disimpulkan sebagian besar mahasiswa memiliki respon 
yang positif terhadap penerapan metode dan media dalam pembelajaran kosakata dan struktur kalimat.

\section{KESIMPULAN DAN SARAN}

\subsection{Kesimpulan}

Hasil penelitian dan pembahasan membuktikan bahwa metode diskusi hasil analisis karya tulis dengan media software ginger dapat meningkatkan penguasaan kosakata dan struktur kalimat Bahasa Inggris Mahasiswa Program Studi D3 Teknik Informatika di Politeknik Gorontalo. Meningkatnya penguasaan ini digambarkan melalui perbandingan data kemampuan awal mahasiswa dengan data hasil tes setelah menyelesaikan siklus I dan siklus II. Berdasarkan hasil penelitian dan pembahasan, mahasiswa memperoleh peningkatan penguasaan dan mampu memenuhi Kriteria Ketuntasan Minimal (KKM) dengan baik sebagaimana yang ditentukan atau ditetapkan sebelumnya.

\subsection{Saran}

Berdasarkan hasil penelitian dan pembahasan diatas, maka peneliti dapat memberikan saran sebagai berikut:

a. Bagi Dosen: Penggunaan metode diskusi hasil analisis karya tulis dengan Media Software ginger dapat menjadi salah satu alternatif menarik untuk meningkatkan penguasaan kosakata dan struktur kalimat Bahasa Inggris. Beberapa hal yang harus diperhatikan adalah pengajaran kosakata dan struktur kalimat akan sangat lebih baik apabila disesuaikan dengan pemilihan tema atau topik yang lebih spesifik dan jelas, sehingga memperdalam penguasaan atau pemahaman materi. Selain itu, diharapkan sebaiknya dosen mampu mengintegrasikannya dengan pemilihan strategi lainnnya seperti teknik, model atau metode yang bervariasi yang mampu memaksimalkan pengajaran dengan menggunakan media ini.

b. Bagi Mahasiswa : Mahasiswa dalam mengikuti proses pembelajaran menggunakan metode diskusi dan media ini hendaknya diharapkan dapat lebih memperhatikan penjelasan-penjelasan dari dosen. Terlebih khusus untuk penggunaan media ini yang sebenarnya dapat dimanfaatkan sebagai alat bantu secara mandiri oleh mahasiswa, akan tetapi membutuhkan keterampilan dengan seksama untuk memilah dan memilih hasil analisis yang dihasilkan melalui penggunaan software ini. Selain itu metode diskusi ini diharapkan mampu memberikan kesempatan kepada mahasiswa dalam mengaplikasikan kemampuan dan keterampilan berkomunikasi mengungkapkan gagasan melalui Bahasa Inggris dengan media ini sebagai alat bantu untuk menguasai kosakata dan struktur kalimatnya.

\section{c. Bagi Program Studi:}

Program studi diharapkan dapat menyediakan atau memfasilitasi berbagai macam media pembelajaran berbasis teknologi yang menyenangkan dan mampu membangkitkan keaktifan dan kreatifitas kepada mahasiswa dalam pembelajaran, sehingga mampu meningkatkan kemampuan penguasaan materi pembelajaran khususnya Mata Kuliah bahasa Inggris I.

\section{DAFTAR PUSTAKA}

Arikunto, dkk. (2007). Penelitian Tindakan Kelas. Jakarta. PT Bumi Aksara

Djamarah, B.S \& Zain.A. (2010). Strategi belajar mengajar. Jakarta. PT. Rineka Cipta

Harmer, J. (2004). The Practice of English Language Teaching. Malaysia. Longman

Pribadi, B.A \& Putri, D.P. (2001). Ragam media dalam pembelajaran.Jakarta: Pusat Antar Universitas Untuk Peningkatan dan Pengembangan Aktivitas Instruksional Universitas Terbuka

Rianto, dkk. (2006). Pendekatan, Strategi, dan Metode Pembelajaran. Malang. Departemen Pendidikan Nasional Direktorat Jenderal Peningkatan Mutu Pendidik dan Tenaga Kependidikan

Sumiati \& Asra. (2007). Metode pembelajaran. Bandung. CV Wacana Prima

Features for improving your English http://www.gingersoftware.com Diakses pada tanggal 10 Oktober 2016. 